\title{
KERK EN KONINKRYK
}

As ons vra wat die kerk is, moet ons onthou dat ons hier besig is met 'n geloofstuk van ons belydenis: „Ek glo aan 'n heilige, algemene Christelike kerk, die gemeenskap van die heiliges" (Apostoliese Geloofsbelydenis). Dit beteken nie dat die kerk onwerklik, irreëel, is nie, maar alleen dat hy na sy diepste wese deur die geloof alleen geken kan word (Hebr. 11 : 1). Net soos die geval is met die Bybel as 'n boek, is daar niks in of aan die kerk wat nie ook gewoon menslik gedui kan word nie, as ons nie deur die geloof verstaan en weet dat dit, as Liggaam van Christus, ten diepste die maaksel van God se hande is nie en dat dit alleen bestaan deurdat Christus deur sy Gees in die harte van die gelowiges woning maak nie.

Daarom word die kerk deur vele gesien as 'n sosiologiese verskynsel en die godsdiens verklaar as vrug van psigologiese en biologiese prosesse. Mense wat die kerk so sien wil dan die kerk gebruik as 'n organisasie vir sosiale welsynswerk, wat met allerlei tegnies-wetenskaplike, ekonomiese en selfs politieke aksies die ontplooiing en groei van die mens en die samelewing moet stimuleer en aanhelp. Langs dié weg sal dan die vrederyk of gelukstaat of koninkryk van God op aarde gevestig en uitgebrei word. Dit is wat vandag bekend staan as die idee van die "Social Gospel". Die kerk kom hier dan te staan as 'n bloot-menslike vereniging of genootskap vir die bevordering van deug en goeie sedes. Die Christendom word gesien as één van die verskillende godsdiensvorme, waarin die mens sy ideale probeer verwesenlik. Christus is 'n ,godsdiensstigter" net soos Mohammed e.a. dit was. Volgens baie (Hegel bv.) is die Christelike godsdiens die hoogste vorm van geestelike ontwikkeling, wat in die filosofie sy eintlike sin en doel bereik, sodat dit dan eintlik ten slotte moet plek maak vir die wysbegeerte, waarin die mens sy diepste geestelike behoeftes ten volle kan uitleef en realiseer.

Die absoluutheid van die Christelike geloof word so geloën en ,verklaar" as 'n toevallige stadium van menslike ontwikkeling wat ten slotte uit en deur en tot die mens is en waar geen bonatuurlike of metafisiese agtergronde voor gesoek moet word nie. Hiermee word ontken dat ,die saligheid in niemand anders (as Christus) is nie, want daar is ook geen ander naam onder die hemel wat onder die mense gegee is, waardeur ons gered moet word nie" (Hand. 4: 12). Hiermee word Christus 
self tot leuenaar gemaak as Hy sê: „Want Ek het uit die hemel neergedaal, nie om my wil te doen nie, maar die wil van Hom wat My gestuur het. En dit is die wil van die Vader wat My gestuur het, dat al wat Hy My gegee het, Ek daarvan nie sal verloor nie, maar dit opwek in die laaste dag" (Joh. $6: 38,39$ ). Vir ons is daar maar net één „Apostel en Hoëpriester van ons belydenis, Jesus Christus". Hy alleen is die gesondene van die Vader (vgl. Hebr. $3: 1$ ).

In so 'n vermenslikte "kerk" kom die belydenis dan al meer op die agtergrond te staan en verval die kerklike tug. En hiermee hang ten nouste saam dat die Heilige Skrif as bron en norm van die waarheid prysgegee is. Dis waarlik pateties om te sien hoe 'n man soos Kraemer bv. worstel om iets te red van die Nederlandse Herv. Kerk, wat volgens hom vóór en na 1816 aan hemeltergende verslonsing ten prooi geval het en wat besig was ,haar tot een volkomen nul te doen verworden", tot „zouteloos zout".' En daarby meen hy dan dat al die rigtinge of modaliteite, selfs van vrysinniges en regsinniges die kerk eerder na 'n hotel as na 'n kerk of huisgesin laat lyk." Sy "oplossing" is dat al die rigtinge sal moet leer wat dit is om kerk te wees en verder dat alle kerke één moet word, om so die Nederlandse volk te kersten. „Ik blijf met blijde verwachting uitzien naar den dag, waarop ik uit naam van en in opdracht der gezamenlijke kerken, voor het werk der herkerstening op één podium zal mogen staan met een Gereformeerden, Remonstranten, Vrijzinnig- of orthodox-Hervormden, Doopsgezinden of Leger des Heils medechristen... ter verkondiging van, de groote werken Gods' ". ${ }^{3}$ Mens vra jou af watter grote werke van God Kraemer in éen koor wil verkondig, saam met loënaars van die Godheid van Christus en sy opstanding en wederkoms? Sal so 'n „kerk" nie sertifiseerbaar wees as 'n skisofreniese en totaal gedesintegreerde „persoonlikheid" wat eerder 'n gevaar as 'n seën vir die wêreld is nie? En dan sal dit voorwaar niks help om, soos Kraemer aan die hand doen te "brul" om die kragtige werking van die Heilige Gees nie." Die Gees werk deur die Woord, en waar vir Gods onfeilbare Woord g'n plek meer is nie, daar word die Gees bedroef en loop die kerke leeg, al "brul" ons nog so hard. Die kerk word nie tevergeefs kerk (Kuriakon - Huis van die Here) genoem nie. Die kerk is die vergadering (Edah = sinagoge) van God se volk, dus die saamtrek of kongregasie van die gelowiges, en word daarom uit die wêreld geroep (convo- 
catio of coëtus), soos die woord ecclesia (Hebr. Kahal) ook aandui. Dis, soos Luther dit gedefinieer het die „communio sanctorum et vere credentium, in qua evangelium recte docetur et recte administrantur sacramenta", dus die gemeenskap van heiliges en ware gelowiges waar Woord en sakramente suiwer bedien word.

\section{Die wese van die kerk}

In verband hiermee word gewoonlik gevra: Wat is die kerk of wat maak die wese van die kerk uit?

Daaroor kan veel gesê word. Die kerk word in die Skrif onder velerlei benamings, meesal beeldspraak, aangedui. Dit word geteken as die volk van God, die ware Israel, 'n huis of tempel van God, die nuwe Jerusalem, die bruid van Christus, die vrou of verloofde van God (Jes. 54, Openb. 19, Ef. 5, Hosea 2 ), burgers van die hemelse vaderland, priesters van die Allerhoogste, skape van Christus waarvan Hy die Herder is (Joh. 10), die uitverkore kinders van die Vader, die wingerd van die Here (Jes. 5), of ranke aan die ware Wynstok, Christus (Joh. 15), dic liggaam van Christus, waarvan Hy die Hoof is (Ef. 1, 4, Kol. 1) ens. Paul Minear haal uit die Nuwe Testament tagtig verskillende terme aan, wat op die kerk toegepas kan word." Maar met dit alles bly dit nog 'n kwessie of ons sinvol kan sê: wat is die kerk? Na alles bly dit 'n misterie wat ons nie in een woord kan omskryf nie, net so min as wat ons eintlik kan sê wat is bv. 'n mens? Ons sou miskien makliker kon antwoord op die vraag wie is die kerk of wie maak die kerk uit? Maar dit bly ten slotte 'n geloofsmisterie waarvan ons alleen deur die verpligting van die Heilige Gees 'n begrip kan kry. As Duvenage sê dat Polman se omskrywing van die wese van die kerk, nl. dat dit die esgatologiese ryksgemeente, die vergadering van die ware Christengelowiges, die liggaam van die volheid van Christus, die tempel van die lewende God is, „duidelik en omvattend" is," dan kan ons saamstem, mits ons dit nie verstaan in empiristiese sin nie, maar as 'n geloofsbelydenis. Dieselfde kan ons sê van wat ons bely in die N.G.B., art. 27-29. Die kerk is ten diepste die verloste mensheid, gesien uit verskillende gesigspunte onder die beelde hierbo genoem, maar wat wesenlik net so misterieus is as wat die mensheid self is. 


\section{Wie maak die kerk uit?}

Hierdie vraag is skynbaar baie maklik om te beantwoord. Ons sou kan sê die kerk bestaan uit alle gelowiges of alle uitverkorenes, ens. Maar dit word moeiliker as ons in die konkreet historiese wêreld moet bepaal waar die grense van die kerk lê. Vir eers weet ons glad nie wie almal uitverkore is nie. Ten tweede kan ons nooit met sekerheid sê of iemand die ware geloof besit nie. Ons kan immers nie oor die harte oordeel nie.

Al wat oorbly is dan om saam met ons belydenis te sê die ware kerk is daar waar Gods Woord suiwer bedien en beleef word. Die kerk op aarde moet sigbaar wees omdat dit uit sigbare mense bestaan wat sigbaar optree in Woord- en sakramentsbediening, en belydenis en wandel, in aanbidding en lofverheffing. En tog kan ons nie direk sien wie gelowig en wedergebore is en wie nie. Ons kan alleen maar oordeel volgens die uiterlike vertoning en dan met meer of minder sekerheid konkludeer dat so 'n lewe en sulke dade getuig van innerlike genade. Maar nooit weet ons onfeilbaar wie se name in die Boek van die Lewe staan nie. Saam met Paulus kan ons maar uitroep: „Ewenwel, die fondament van God staan vas met hierdie seël: die Here ken die wat syne is, en: Laat elkeen wat die Naam van Christus noem, afstand doen van ongeregtigheid" (2 Tim. 2 : 19).

Net soos wat ons geen volmaakte gelowige op aarde kry nie, so kry ons ook nêrens 'n volmaakte kerk nie. Ons glo aan één, heilige, algemene (katolieke), Christelike (apostoliese) kerk. Maar waar is daardie én kerk? Waar is die kerk as 'n heilige openbaring van die katolieke Liggaam van Christus?

Hiermee wil ons egter nie verval in relatiwisme of sinkretisme nie. Ons moet ook as kerk die volmaaktheid najaag of ons dit kan gryp (Fil. $3: 12$ ). Net soos elke gelowige homself daagliks moet bekeer en toeneem in die heiligmaking, net so moet ook die kerk hom gedurig bekeer en reformeer, om te wees 'n pilaar en grondslag van die waarheid.

Alleen so sal die kerk tot 'n seën vir die wêreld kan wees. As die evangelie sy krag openbaar binne die kerk as 'n suurdeeg wat die kwaad uitsuiwer, alleen dan sal die kerk ook krag kan uitoefen na buite in die wêreld.

Blote eenheid sonder meer sal geen krag aan die kerk gee nie. Alleen wanneer elke gelowige 'n lewende en persoon- 
like draer is van die evangelie wat self daardeur aangegryp en vernuut is, dan sal so ' $n$ kerk in volle sin ook ' $n$ skynende lig en 'n soutende sout in die wêreld kan wees.

Die wese van die kerk kan dus ook nie gesoek word in die Apostoliese suksessie of die ampsuitoefening sonder meer nie. Die kerk is die volk van God en die ampsmag wat charismaties van aard is, rus ten diepste in die gelowiges wat tot die kudde van Christus behoort. Neill wys daarom daarop dat die Geesvervulde kerk nie 'n starre eenheid sal vertoon nie, maar juis die verskeidenheid van gawes en bedieninge sal beklemtoon. En dan is die sogenaamde besondere ampte maar net ' $n$ bepaalde wyse van ampsuitoefening wat nie die algemene $a m p$ van die gelowiges moet vervang nie, maar juis stimuleer.'

In ' $n$ artikel oor dr. Sasse in The Reformed Theol. Review deel prof. Runia een en ander mee oor 'n boek wat uitgegee is in verband met Sasse se sewentigste verjaarsdag. Dit bevat 27 stukke wat Sasse geskryf het, o.a. ook oor die kerk. Sasse sê dat ons in Art. 7 van die Augsburgse Konfessie die eerste dogmatiese formulering in die geskiedenis van die Christendom vind aangaande die kerk se aard en eenheid." Die artikel lui soos volg: „It is also taught among us that one holy Christian church will be and remain forever. This is the assembly of all believers among whom the Gospel is preached in its purity and the holy sacraments are administered according to the Gospel. For it is sufficient for the true unity of the Christian church that the Gospel be preached in conformity with a pure understanding of it and that the sacraments be administered in accordance with the divine Word. It is not necessary for the true unity of the church that ceremonies, instituted by men, should be observed uniformly in all places. It is as Paul says in Eph. $4: 4,5$,There is one body and one Spirit, just as you were called to the one hope that belongs to your call, one Lord, one faith, one baptism' ", (vertaal uit die Duits deur T. G. Tappert, 1959) " Volgens Sasse word hier g'n onderskeid gemaak tussen ' $n$ sigbare en onsigbare kerk nie. Dit is terselfdertyd 'n vergadering van gelowiges, wat gesien kan word en wat as gemeenskap van heiliges die onsigbare Liggaam van Christus uitmaak. So is ook die eenheid van die kerk 'n sigbare eenheid en tog ook weer terselfdertyd 'n onsigbare geestelike eenheid in Christus.

Nou kom die vraag egter op of hiermee beantwoord is 
wat die kerk eintlik in sy wese is? Die Rooms-Katolieke het eers onder invloed van Augustinus die kerk gesien as identies met die koninkryk Gods. Later het die nadruk geval op die kerk as die mistieke Liggaam van Christus en sinds Vaticanum II word die kerk nou veral gesien as die volk van God.

In die tweede Helvetiese Konfessie word die kerk beskryf as 'n uitverkore vergadering van gelowiges, die gemeenskap van die heiliges, wat God in Christus waarlik ken en reg dien deur die Woord en Gees en wat deel het aan die genadegawes van Christus, burgers van die hemelse stad (Ef. 2 : 19), geheilig deur die bloed van die Seun van God (Hfst. XVII).

So kan daar veel aangaande die kerk gesê word, bv. soos ook in Art. 27 van die N.G.B. Die kerk is ,'n heilige vergadering van almal wat waarlik in Christus glo, wat hulle hele saligheid in Jesus Christus verwag en gewas is deur sy bloed, geheilig en verseël deur die Heilige Gees".

Die kerk is aangedui as gelowiges, heiliges, uitverkorenes, wedergeborenes, ens.

Maar dit alles sê nog nie presies wat die kerk is nie. Ons kan wel wys op die ontstaan van die kerk, sy omvang en taak, sy funksie en doel. Maar nog steeds bly die vraag wat die kerk in sy diepste wese is?

As ons besin oor die wese van die kerk, kan ons eintlik nie anders sê as dat die kerk uit mense bestaan, sy dit dan ook 'n besondere genre van mense, $n$ l. gelowiges of geheiligdes of wedergeborenes of uitverkorenes, watter aspek ons dan ook al wil beklemtoon. Ons kan in organiese sin ook van die kerk praat as die nuwe, verloste, wedergebore, geheiligde mensheid, wat in Christus deel het aan die ewige lewe wat $\mathrm{Hy}$ vir ons verwerf het.

\section{Kerk en koninkryk}

Soos ons dit sien is die kerk en die wêreld, te midde van die stryd en ellende wat daar in beide te sien is, nogtans die koninkryk Gods in wording, omdat Christus, die Koning, opgestaan en also oorwin het en tans uit die hemel besig is om sy koninkryk tot voltooiing en afronding te bring. Hierby is die kerk die avant garde, die eintlike spits van die strydmagte op die slagveld, maar die ganse wêreld is tog daarby betrokke.

Die fout by Rome is dat hulle die kerke gaan sien het 
as die koninkryk Gods en die wêreld daarteenoor as die ryk van Satan (Augustinus), iets wat tot sekere mate ook by die Lutheranisme deurgewerk het in die twee-regimenteleer van Luther. Die lyn word dan getrek tussen die kerk as instituut en die terrena profana, in plaas van die geestelike grens tussen Christus en Belial wat deur die ganse lewe heen loop. Die kerk word die sanctuarium waarbinne die heilsweldade verkry en geniet word deur middel van die amptelike bediening. Die ampsdraer word gesien as iemand wat feitlik die beliggaming is van bonatuurlike ampsheiligheid, en so verkry die amp self 'n soort sakramentele karakter as bron van krag en heiligheid. Die neiging om die amp (resp. ampsdraer) te vergoddelik in meerder of minder mate, werk soms selfs in die Geref. Kerkbeskouing nog deur, veral daar waar die Kollegialisme beslag gekry het. Mens merk bv. by Van Ruler iets daarvan as hy sê: „Hoe ben ik het eeuwige leven en het eeuwige ryk deelachtig? In m'n geweten? In m'n bevindingen? In m'n existentie? In m'n medemenslikheid? In m'n cultuurarbeid? In het grootse, ruige leven in de wereld? Ach neen: tenslotte slechts in een brokje brood en een slokje wijn!" ${ }^{10}$ Omdat die kerk genoem word 'n woonstede van God in die Gees, sê Van Ruler: „Het is zelfs de vraag, hoe die kerk ooit volledig aan een zekere zelfvergoddelijking kan ontkomen"." Hy sien in die kerk die realiteitsgestalte van die inkarnasie van Gods Seun en die inhabitasie van die Heilige Gees. „De kerk is een van de diepe mysteriën van het heil en van het zijn". En daarom is dit vir hom verstaanbaar dat daar 'n sekere introversie by die kerk is en verwag hy van die lidmate om „domweg regelmatig naar de kerk te gaan"." Daarom meen Van Ruler dat die besondere amp ook 'n besondere klem verkry, omdat daardeur Christus amptelik, gesagvol aan die gemeente bedien word. Die heil in Christus is iets wat gekenmerk word deur "bijzonderheid en vreemdheid", wat aan die oorspronklike menslike eksistensie "toegevoegd" word. ${ }^{18}$

Hierdie hele betoog van Van Ruler maak die indruk van 'n teëstelling wat hy sien tussen natuur en genade. Vandaar sy sterk beklemtoning van die besondere amp in die kerk. Christus is tog waarlik nie net in die stukkie brood en die slukkie wyn teenwoordig nie, maar dit is maar die simbool en seël van sy teenwoordigheid „,in het grootse, ruige leven in de wereld".

G'n wonder dat Van Ruler dan ook niks wil weet van 
'n amp van die gelowige in die kerk nie. „Dan stond de gelovige toch weer aan de zijde van God. En het is de bedoeling, dat hij juist in een tegenóver met God staat en stand houdt". Dan, sê hy, kan mens nooit eens ,helemaal lekker zichzelf zijn”, omdat jy iets verteenwoordig wat „hoogst dubieus, in ieder geval onzichtbaar is" en word jy gedring om op te tree as advokaat van God." Nee, vir Van Ruler is al hierdie besondere dinge verbonde aan die besondere ampte. ${ }^{15}$

Dit behoef seker g'n betoog dat Van Ruler 'n fundamentele fout maak in sy hele uitgangspunt, nl. dat Christus en sy heil iets "vreemds" is wat aan ons eksistensie toegevoeg word. So kom hy in Roomse vaarwaters.

Die vraag ontstaan: Wat is die posisie en taak van die kerk ten opsigte van die opbou en uitbreiding van Gods koninkryk in die wêreld?

Ons praat bv. van 'n openbare erediens. Maar wat verstaan ons presies daaronder? Is daar nie 'n neiging om dit eerder te sien as 'n geslote samekoms in 'n beslote kring nie? Verstaan die wêreld (en die kerk self) dit nie meesal so dat alleen die gelowiges, die gemeente, binne in die kerkgebou welkom is nie al staan die deure ook oop? En word die kerk dan so nie verander in 'n soort klub nie? En ontstaan op die wyse nie 'n soort fariseërs-hooghartige gees van eksklusiwisme by die gemeente nie?

Nou weet ons wel dat die erediens in die eerste plek 'n vergadering van die gelowiges is, wat kom om God te ontmoet, Hom te aanbid en hul nood voor Hom te lê. Maar wanneer bv. die Woord bedien word, is dit dan eksklusief gerig op die gelowiges om hulle te sterk, te vermaan, te troos en te onderrig? En moet die wêreld dan daarnaas deur sending en evangelisasie bearbei word deur 'n helemaal aparte aksie van die kerk? So word dit veelal gesien. Die mense wat nie lede van so 'n gemeente is nie, is huiwerig om binne te gaan in wat vir hulle lyk soos 'n soort ghetto, waar hulle as vreemdelinge dadelik opgemerk sal word

Die vraag is of die grondfout nie is dat die besondere ampte in die kerk mettertyd 'n stelsel van hiërargie, sakerdotalisme, priesterheerskappy of klerikalisme geword het nie, waardeur dit los van of teenoor die gemeente te staan gekom het as bemiddelend van aard, sodat dit dan uitsluitlik op die gemeente gerig word, wat as "leke" passief maar net toeskou en ontvang? Dit is dus nie die gemeente wat deur die besondere 
ampte die wêreld bedien met die evangelie nie, en so verloor die kerk dan eintlik sy wêreldverowerende taak in diens van Gods koninkryk.

\section{Die koninkryk Gods en die wêreld}

As ons vra wat is die verhouding van die koninkryk Gods tot die wêreld, dan moet ons dit seker so sien dat die wêreld nie alleen die skoutoneel (Schauplatz) is waarop die koninkryk opgerig sal word nie, maar dat die wêreld, wat Christus met sy bloed gekoop het, waaroor Hy heers en wat in beginsel saam met Christus uit die graf opgestaan het en in Hom verheerlik is, ' $n$ verloste wêreld is, ' $n$ wêreld wat op pad is na die volsalige heerlikheid, 'n wêreld wat dus eintlik die wordende koninkryk der hemele is.

Daar word in ons tyd veel gemaak van die sg. sekularisasie van die wêreld. Die bedoeling is dan dat ons as gelowiges die wêreld nie sien as openbaring van die wese van God of van gode of demone nie. Die natuur is skepsel en het as sodanig in geen opsig deel aan die goddelike nie.

Tog moet ons hier baie versigtig wees. Hierdie sogenaamde sekularisasie kan baie maklik lei tot algehele „ontgoddeliking" van die wêreld, waar God nie alleen g'n plek hoegenaamd meer het nie maar waar Hy ten slotte nog net as „,dood” gesien word. En so word dan die ruimte geskep om die onttroonde God te vervang deur die mens, wat gesien word as skepper van sy eksistensie en bepaler van sy eie lot. In plaas van godsdiens kry ons dan mensediens, en religie bestaan in die kultus van „medemenslikheid", wat dit ook al mag beteken.

Teenoor „sekularisasie” sou ons eerder wil stel „sanktifikasie" of „verchristeliking" van die wêreld, wat aandui dat die wêreld en alle lewensterreine aan God gewy moet word, omdat dit aan Hom alleen behoort. Dit beteken nie verkerkliking of hiërargiese oorheersing, soos by Rome nie. Daarom sou ons liewer nie van ,sakralisering" van die wêreld nie, maar wel van sanktifikasie of heiliging wou praat.

\section{Die wêreld en die koninkryk Gods}

Barth word dikwels beskuldig van Christomonisme, omdat Hy die hele wêreldproses (insluitende die skepping van die wêreld) so sterk verbind aan die inkarnasie van Gods Seun, aan Jesus van Nasaret. Nou kan ons dit seker nie aanvaar op 
die wyse waarop Barth die gedagte uitwerk nie. Hy sien die historiese proses te veel net as heilsgeskiedenis en huldig daarby 'n onbybelse universalisme, waarby die historiese wel ten slotte in geheel wegsink in die dood, maar terselfdertyd as "Geschichte" in Christus herrys tot die ewige lewe.

Nogtans sit daar iets waaragtig en aangrypend in die visie van Barth. Hy verwag wel g'n heil van die natuur as sodanig nie, hy glo nie aan gemene grasie nie, ook nie aan natuurlike teologie nie. Nee, alles kom van Christus alleen. Maar Barth se fout is dat hy die natuur laat ondergaan in die reddingsproses. Hy is so ingestel op die soteriologie dat hy vir God se openbaring in die skepping as sodanig nie meer oog het nie. Vandaar die geweldige reaksie en terugswaai van die pendulum in die rigting van die algemene openbaring en natuurlike teologie, soos dit vandag veral in Amerika sy beslag kry in die ,death of God"-teologie en in die algemeen in die anti-metafisiese denkrigting en eksistensialistiese mensvergoding van ons tyd.

Daar sit wel iets in die Barthiaanse visie van die sentraliteit en kosmiese omvattendheid van die Christusgeskiedenis of -gebeure, as ons dit so mag noem. Al verwerp ons sy dialektiese siening van die predestinasieleer, neem dit nie weg dat ons die wêreld en die geskiedenis in beweging moet sien, naamlik die beweging van die koms (en wederkoms) van Christus wat uiteindelik sal lei tot die eksplosie van die hemele en die aarde ( 2 Pet. $3: 10$ ), en die geboorte daaruit van nuwe hemele en nuwe aarde, waarop geregtigheid woon (vs. 13). Ons leef dus nie "tussen die tye" van die koms en wederkoms van Christus nie, soos Barth dit het, maar in die tyd van die koms van Christus, die "laaste uur" (1 Joh. $2: 18$ ), die groot en vreeslike „dag van die Here", wat sy hoogtepunt en afronding sal vind met die verskyning van Christus op die wolke, om te oordeel en die wêreld tot sy ewige bestemming te bring.

Dit is dus nie maar 'n kwessie van wag vir die koms van Christus nie, waarin ons ons onledig moet hou met 'n soort kultuurprogram, as byvrug van menslike ontwikkeling of van sosiale en ekonomiese eksploitasie van immanente, sekulêre kragte en potensies nie. Ook mag ons nie agter kloostermure afsonder van die wêreld en 'n kluisenaarsbestaan voer in ' $n$ wêreld nie wat rondom ons vergaan en wat skreeu en kerm in sy geestelike en stoflike nood. So 'n "Christendom" verdien om gehaat en verfoei te word, want dit is presies die teen- 
oorgestelde van wat Christus voor geleef en gesterf het. Hy wou Homself nie red van die kruis nie, omdat Hy die wêreld wou red, al het dit Hom ook sy lewe gekos.

\section{Christus kom altyddeur - Maranata}

As ons sê: Christus kom altyddeur, wil ons daardeur vir g'n oomblik 'n streep trek deur sy aanstaande finale wederkoms op die wolke en die laaste oordeel nie. Inteendeel wil ons dit dan so juis benadruk en beklemtoon as die grootse en heerlike voleinding en afronding van sy koms en verlossingswerk deur die eeue heen.

Maar daarby moet ons dan in gedagte hou dat sy tweede koms juis is om sy oorwinning oor die magte van die duisternis te beklink en die wêreld tot sy ewige bestemming in heerlikheid te bring en aan God oor te gee as die kroon op sy stryd en arbeid dcur die lange bange eeue heen. Dan word die vrugte van sy lyde gepluk en die oes in groot blydskap ingesamel (Ps. 126, Matth. $13: 36-43$, Openb. $14: 14-20$, Joël $3: 12-14$, Matth. $3: 12$ ).

In ' $n$ bepaalde sin kan ons dus sê dat Christus kom van die verlore paradys in Eden af tot by die herstelde paradys op die nuwe aarde. Alles wat die Bybel ons meedeel is die vervulling van die moederbelofte in Gen. $3: 15$.

Die O.T. was nie maar net 'n tyd van afwagting nie. Dit is ook nie so dat God die wêreld duisende jare lank maar net laat $l \hat{e}$ en aan homself oorgegee het nie, terwyl Hy Hom dan net tot Israel beperk en daarin die saad van die vrou, die beloofde Messias, voorberei het nie. Nee, God het wel toegelaat dat die nasies in hul eie weë wandel, maar daarby Homself nooit onbetuig gelaat nie (Hand. $14: 16,17$ ).

Die wêreldgeskiedenis is nie 'n sameflansing van los gebeurtenisse nie. Dis één grootse program van Goddelike aksie. Vgl. Daniel 2. Dis 'n magtige plan de campagne of krygsplan wat deur Christus in alles en almal uitgevoer word en waarvan al die besonderhede in God se Raad soos in 'n boekrol opgeteken staan (Openb. 5).

Christus het dus nie maar op ' $n$ willekeurige tyd gekom met sy geboorte in Betlehem nie. Nee, Hy het gekom in die volheid van die tyd (Gal. $4: 4$ ).

En sy sogenaamde tweede koms is in werklikheid die voortsetting en voltooiing van sy eerste koms in die vlees. 
Ons leef in die finale fase van die wêreldgeskiedenis, waarin Hy elke dag besig is om te kom en om gou te kom, soos die laaste Bybelboek in sy laaste hoofstuk so sterk beklemtoon. Daarom praat die Skrif van die „dag” en selfs die „uur" van sy wederkoms, soos Johannes ook sê: „Kinders, dit is die laaste uur" (1 Joh. 2 : 18).

Dit is dus nie so dat die wêreld gered word deur 'n bloot "historiese" gebeurtenis wat tweeduisend jaar gelede in Betlehem en op Golgota afgespeel het en wat as 'n historiese feit eenvoudig tot die verlede behoort nie.

Nee, ons het te doen met die lewende God wat altyddeur werk en wat altyddeur kom om die wêreld te verlos. Wat nou en hier daarmee besig is en dit weldra sal afrond met die „wedergeboorte" van 'n nuwe hemel en 'n nuwe aarde (Matth. 19 : 28; Jes. $66: 22$; Petr. $3: 1-13$ ).

\section{Eindig die geskiedenis by die voleinding?}

Prof. H. Roberts wys daarop dat voleinding beteken vervulling en nie beëindiging nie. Hy wys in die verband op Jesus se woorde in Matth. $5: 17$. En dan sê hy: „Everything that God has wrought within that age (d.w.s. ,present age") in the material universe and in the life of man will be carried to fulfilment in a reconstituted universe, a new heaven and a new earth". Daarom en daarin sal die ewige lewe 'n ewige fees wees (Luk. 19 : 12-27). Roberts meen dat vervulling nie groei en skeppende aktiwiteit uitsluit nie. In die volmaaktheid sal wel g'n stryd of frustrasies meer wees nie, maar daar sal nog ",abundant opportunity for exploration and discovery" wees. Ons insig daar sal steeds nog verryk en verdiep word, wat ons tot groter aspirasies sal dryf. "Love is ever creative"."

Ons stem volkome saam met Roberts dat die lewe en die geskiedenis nie sal gaan stilstaan na die „voleinding” nie. Maar dat dit sal voortgaan in die vorm van kreatiewe aktiwiteite en nuwe ontdekkinge, skyn ons nie 'n adekwate, maar 'n al te mondiale en „diesseitige” opvatting te wees. Feit is dat die geskiedenis hier op aarde eintlik 'n stryd teen die sonde en die dood is, albei faktore wat daar in die hiernamaals nie meer sal bestaan nie. Dit skyn ons eerder of die aktiwiteit dáár sal bestaan in die altyd dieper indring in die Goddelike heerlikheid en saliger genieting van God se gemeenskap en voller uitlewing van ons menswees, tot eer van God. Dit impliseer 
geen tekort of gebrek nie maar ontplooiing van heerlikheid tot heerlikheid.

\section{'n Gesekulariseerde Christendom}

Die idee van die koninkryk Gods as 'n aardse Utopia (social gospel - Rauschenbusch), het deur die ekumenisme van ons tyd 'n geweldige stoot gekry. Daar word onder allerlei tradisioneel-christelike terme 'n nuwe "wêreldgodsdiens" ingevoer, gebaseer op die gedagte van die broederskap van alle mense, wat almal in Christus God tot Vader het en wat die godsdiens beleef as algemene mensediens, sodat God as transendente Wese uitgeskakel word (,dood is") en alleen in ons immanente ervaringswêreld geken en ervaar word.

In 'n artikel: „Christianity without God" gee William Leroy enige treffende aanhalinge van hierdie nuwere "Christendom", van wie sommige leiers hulself bestempel as Christelike ateiste. Hy verwys na wat Elisabeth Adler skryf oor "Worship in a secular age" in „Student World", nr. 1, 1963, p. 88. Sy beskryf die sekularisme as 'n maatskappy wat hom van religieuse outoriteit losgemaak het. Verder: „A secular society is one in which a large place is given to perpetual and creative doubt, to total re-examination in freedom". Sy sê dat die sekularistiese denke funksioneel en nie ontologies van aard is nie. Alles wat ontologies aangedui word moet uit ons gebedeboeke weggehaal word. Leroy haal ook aan wat dr. Kraemer gesê het, naamlik dat die sekulariserende tendens van die moderne uitkyk ,implies the atrophy of the religious constituent in human nature. By its inherent persistent striving to master the world and subject it to the quasi-omnipotence of human insight and manipulation, it impels at the same time towards a self-sufficient, purely profane antropocentrism and towards a no less distinct selfalienation of man. It forces men automatically into an excessive preoccupation with the pursuit of worldly ends, with progress, with ever faster change. It generates a massive suggestion towards a purely immanent view of life. This secular immanentism must be stressed, because it presupposes and engenders a religionless world. A world in which God is superfluous, squeezed out and absent" (H. Kraemer: World cultures and world religions, p. 347).

Leroy verwys na andere by wie die sekularisme gelei het tot die nihilisme van Nietsche: Die mens se lewe word totaal 
onpersoonlik en dit lei tot onenigheid en konflikte. „Superstitions abound where the church has lost its power". Hy verwys ook na Wilmore (The secular relevance of the church, p. 21) wat outentieke sekularisasie daarin sien dat daar 'n wêreldvrederyk ontstaan waarby Christus eintlik as 'n Rewolusionêr gesien word wat God teruggebring het in ons gewone alledaagse lewe, en veral in die rekonsiliasie van die wêreld wat hom uitwerk in die ,humanization of technological society, for the renovation of truth and beauty, for the defense of freedom and social justice". Daarteenoor sien hy dan die sogenaamde ,spurious secularism" wat bestaan uit 'n moralistiese beweging om siele te red.

Leroy verwys ook nog na dr. Marikawa van die Amerikaanse Baptiste Konvensie wat verklaar het dat evangelisasie eintlik onnodig is ,because all men already belong to Christ... for men are no longer lost in a hell of alienation but are already in the kingdom of fellowship and love". En so gaan Leroy voort. Ons haal nog net aan wat hy sê van dr. Cox, wat ook 'n sosialistiese voorvegter is en wat gesê het dat „Today in Movements of liberation of oppressed peoples all over the earth we may see the Exodus repeated... Remember that Jesus made a deliberate decision to step out of the organized church of His day and join the radical movement of John the Baptist... One does not meet Christ in the secret closet of one's heart any more, but one meets Christ, in the streets, in the concrete encounter with one's brother struggling for freedom' "."

\section{Kerk en wêreld}

Die kerk op aarde, as vergadering van gelowiges, is in sekere $\sin$ 'n corpus alienum of Fremdkörper in die wêreld. Christus sê: „As julle van die wêreld was, sou die wêreld sy eiendom liefhê. Maar omdat julle nie van die wêreld is nie, maar Ek julle uit die wêreld uitverkies het, daarom haat die wêreld julle” (Joh. 15 : 19), en weer: „Ek bid nie dat U hulle uit die wêreld wegneem nie, maar dat $U$ hulle van die Bose bewaar. Hulle is nie van die wêreld nie, net soos Ek nie van die wêreld is nie... Soos U My gestuur het in die wêreld, het Ek ook hulle in die wêreld gestuur" (Joh. $17:$ 15-18).

Tog beteken dit nie dat die gelowiges indifferent of vyandig teen die wêreld staan nie. Hulle het 'n duidelike taak en 
roeping teenoor die wêreld (gesien as die invloed- en magsfeer van die Bose), en dit is om as gesondenes (gesante) van Christus die wêreld positief te benader en op te roep tot bekering tot die lewende God. Dit kan hulle maklik hul lewe kos, soos Christus en sovele martelare hul lewens afgelê het. Daarom het Christus gesê: „As die wêreld julle haat, moet julle weet dat hy My voor julle gehaat het" (Joh. $15: 18$ ).

Daar is dus wel waarheid in wat Van Ruler sê dat daar 'n sekere „apartheid" is tussen kerk en wêreld. „Zij is een volk temidden van de volkeren der aarde". ${ }^{8}$ Die kerk en die wêreld is nie identies nie, soos wat die gesekulariseerde kerkbegrip al meer heen neig. Van Ruler bring dit in verband met die inkarnasie van Christus. Hy sê dat die apartheid van die kerk lê in die apartheid van Christus. „Hij is een eigen instantie. $\mathrm{Hij}$ is een realiteit. $\mathrm{Hij}$ is in het geheel niet een chiffre, een ideogram ... wij moeten in Hem ingelijfd worden". ${ }^{19}$ Dit moet kom tot die praesentia realis Christi ipsius, sê hy, en 'n unio mystica cum Christo. „Dat is een heel andere presentie dan onze présence au monde". ${ }^{*}$ Ons as Christene moet dus 'n sekere askese betrag.

\section{Kerk en koninkryk}

Die vraag is of die kerk dit as sy taak moet sien om die koninkryk Gods in die wêreld in te dra of om die koninkryk op te bou deur redding van mense (siele) uit die wêreld uit? In 'n belangrike artikel oor „The pentecostal ,conquista' in Chile" wys C. L. d'Epinay daarop dat die pinksterbeweging of Pentecostalisme veral sinds 1930 sterk afmetings begin aanneem het in Suid- en Noord-Amerika en in dele van Europa, veral Skandinavië." Dit is veral uit die laere, armer klasse gebore, wat eintlik g'n stand het in die samelewing en wat hulself nie kan uitleef nie in 'n kerk, waar daar eintlik 'n kloof tussen die geleerde en gesofistikeerde predikante-stand en die gewone kerkvolk ontstaan het.

Wat ons hier egter op wil wys is wat 'dEpinay skryf oor die koninkryksverwagting by hierdie Pinksterbeweging. Dit blyk dat hulle in baie opsigte ' $n$ soort kommunistiese heilstaat verwag, net soos die Sosiaal-Demokrate e.a. Maar hulle sien dit nie as ' $n$ immanente ryk wat hier op aarde tot stand sal kom nie, maar as 'n transendentale ryk, waarheen die mense uit die wêreld gevoer moet word. Die mensdom moet gered 
word uit die wêreldsee van ellende en dood. Die kerk is hier 'n toevlugsoord vir drenkelinge, ,without a thought for how the angry sea might be calmed"." Die wêreldbeskouing is dus absoluut dualisties, waarby kerk en wêreld, God en satan, die geestelike en stoflike in radikale opposisie is. Die kerk is nie die begin van die koninkryk nie, maar 'n blote teken daarvan. Die Pentekostalisme is daarom a-polities, terwyl die Sosialisme daarenteen sy heil sien in die politiek. By hierdie Gees-beweging gaan dit meer om in standhouding van die bestaande orde as om rewolusionêre omkering daarvan. Hulle is meer ingestel op mistieke versinking en gees-vervoering as op wilsbesluite en aksie, op wêreldontvlugting as op wêreldverandering.

Die Skrif leer ons dat ons as gelowiges in die wêreld moet wees, alhoewel nie van die wêreld nie (Joh. $17: 14-16$ ). Daar is in hierdie sin 'n radikale verskil tussen kerk en wêreld, net so radikaal soos tussen lig en duisternis, tussen lewe en dood.

As die Wèreldraad van Kerke by sy vergadering van Nieu-Delhi (1961) nou verklaar: „The Church is nothing other than a segment of the world which confesses the universal Lordship of Christ. Thus it is the place where the world becomes aware of its true destination, its true face. The Church is the sign or the instrument by which God reveals himself to the world which is still unaware of his reconciliation. It does not exist for itself, but for those who are not of it. It is Mission"," dan moet ons hierin 'n halwe waarheid sien en in daardie vorm baie gevaarlik, omdat dit eintlik die verskil tussen kerk en wêreld uitwis of vervaag.

Daar is wel iets in dat die kerk die verloste en vernude deel van die wêreld is, dat die kerk die egte mensheid vertoon, dat in Christus die kerk (en dus in beginsel die wêreld) verlos is en daarvan steeds meer en meer bewus moet word en dit gaan belewe. Maar daarby bestaan daar nog altyd 'n onoorbrugbare teëstelling tussen kerk en wêreld, net soos tussen Christus en Belial. En nooit mag die kerk universalisties opgevat word as omvattende in wese die hele mensheid, waarvan daar nog net 'n deel, nl. die gelowiges, tot bewussyn gekom het van wat alle mense in Christus besit as synde potensiële of latente Christene en kinders van God, sodat ons taak dan eintlik net is om die mense hul eie diepste self te leer ken en hul eie gesig terug te leer kry, soos wat God hulle eintlik sien nie.

Dat Christus Koning is van die wêreld en elke dag en oomblik besig is om sy koninkryk te vestig en uit te brei in 
die wêreld, is ongetwyfeld waar. Maar dit dan nie langs die weg van ewolusie en selfrealisasie van die mensheid nie, maar langs die weg van roeping en wedergeboorte, deur sy Woord en Gees, van neerwerping van die poorte van die hel. Die ryk van duisternis klaar nie op tot die ryk van die lig nie, maar word daardeur verslind en vernietig.

P.U. vir C.H.O.

S. J. van der Walt.

1 De roeping der Kerk, p. 86.

2 A.w., p. 88

3 A.w., p. 116

4 A.w., p. 84

5 Vgl. S. C. W. Duvenage: Kerk, volksjeug, p. 42.

6 Idem, p. 50.

7 Kyk Interpretation; Vol. XIX, nr. 2, pp. 139-140.

8 Reformed Theol. Review; Vol. XXVII, nr. '1, p. 4.

9 Kyk: Creeds of the Churches, deur J. H. Leith, p. 64 e.v.

10 Geref. Theol. Tijdschrift, Aug. 67, p. 178.

11 Id., p. 179.

12 Ibid., p. 179

13 Id., p. 180, 181.

14 Id., p. 184, 185.

15 Grosheide sê by die verklaring van Matth. $23: 8$ „Laat julle nie Rabbi noem nie, want een is julle leermeester, Christus, en julle is almal broeders" - „dat, omdat éen, dat is Jezus, zelf Leraar is en al die gemeenteleden gelijk zijn". Hierin sien Grosheide nie 'n loëning van die amp nie, maar dit het slegs dienende karakter. Verder: „De scheidslijn loopt niet zoo, dat aan de ééne zijde Xtus en de ambtsdragers staan, aan de andere de leden der gemeente, de kloof ligt na Christus". Kyk sy groot kommentaar op die N.T.

'16 „Jesus and the kingdom of God"; p. $112 \mathrm{v}$

17 "Christianity without God", by William R. Leroy, in Christian Beacon. Vol. XXXI, nr. 12, p. 7.

18 Kyk Geref. Theol. Tijdschrift, Augustus 1967, p. 176.

19 Idem, p. 177.

20 Ibid.

21 The Ecumenical Review, Vol. XX, nr. 1, p. 16 e.v.

22 Id., p. 24.

23 Aangehaal deur R. Brown in 'n artikel "May a reformed Church join the W.C.C.?" Torch \& Trumpet, vol. 17, nr. 3, p. 10. 